\title{
The systemic herbicide 2,4-Dichlorophenoxyacetic acid (2,4-D) is another hormetin: What does it mean for agriculture and the environment?
}

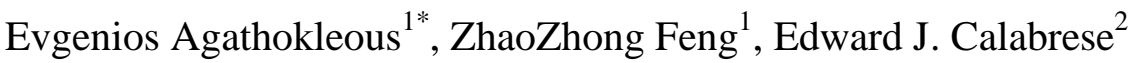 \\ ${ }^{1}$ Institute of Ecology, Key Laboratory of Agrometeorology of Jiangsu Province, School of \\ Applied Meteorology, Nanjing University of Information Science \& Technology, Nanjing \\ 210044, China. \\ ${ }^{2}$ Department of Environmental Health Sciences, Morrill I, N344, University of Massachusetts, \\ Amherst, MA 01003, USA. \\ *Correspondence and requests for materials should be addressed to E.A. (evgenios@nuist.edu.cn).
}

\section{Reference support:}

Massive documentation of the occurrence of hormesis in the recent years suggests hormesis is a common phenomenon, creating a sort of revolution in chemical and environmental toxicology ${ }^{1-13}$.

An assessment of the literature revealed a list of studies with data supporting 2,4-Dinduced hormesis for several traits (e.g. growth, biomass, yields) of a variety of species of algae ${ }^{14}$, macrophytes ${ }^{15,16}$ and higher plants ${ }^{17-30}$, as well as in human dental pulp stem cells ${ }^{31}$. The quantitative characteristics are in agreement with the hormesis characteristics in the broad toxicological and pharmacological literatures ${ }^{6}$.

These findings are important because they suggest that low doses of 2,4-D can stimulate the performance of field crops cultivated in the agricultural practice, such as cotton 17,18,23,32, maize ${ }^{25,33}$, oat ${ }^{26}$, soybean ${ }^{27}$, field bean ${ }^{28,29}$, wheat ${ }^{30}$ and potato ${ }^{22}$, when applied either at vegetative stage ${ }^{17,18,23,24}$ or via seed soaking ${ }^{25,33}$. 
Low-dose stress can alter the chemical composition of agricultural products ${ }^{5,34,35}$.

Low-level stress effects may also have unpredictable ecological/environmental effects ${ }^{5,34-}$ 36.

Nanomaterials widely induced hormesis in plants and algae ${ }^{5}$. Among them, chitosanbased nanoparticles may offer a novel means towards lower concentrations and less applications of herbicides ${ }^{37}$.

References

(1) Costantini, D.; Borremans, B. The Linear No-Threshold Model Is Less Realistic than Threshold or Hormesis-Based Models: An Evolutionary Perspective. Chem. Biol. Interact. 2019, 301, 26-33. https://doi.org/10.1016/J.CBI.2018.10.007.

(2) Costantini, D. Hormesis Promotes Evolutionary Change. Dose-Response 2019, 17 (2), 14. https://doi.org/10.1177/1559325819843376.

(3) Gressel, J.; Dodds, J. Commentary: Hormesis Can Be Used in Enhancing Plant Productivity and Health; but Not as Previously Envisaged. Plant Sci. 2013, 213, 123-127. https://doi.org/10.1016/j.plantsci.2013.09.007.

(4) Morkunas, I.; Woźniak, A.; Mai, V.; Rucińska-Sobkowiak, R.; Jeandet, P. The Role of Heavy Metals in Plant Response to Biotic Stress. Molecules 2018, 23 (9), 2320. https://doi.org/10.3390/molecules23092320.

(5) Agathokleous, E.; Feng, Z.; Iavicoli, I.; Calabrese, E. The Two Faces of Nanomaterials: A Quantification of Hormesis in Algae and Plants. Environ. Int. 2019, 131, 105044. https://doi.org/10.1016/j.envint.2019.105044.

(6) Calabrese, E. J.; Agathokleous, E.; Kozumbo, W. J.; Stanek, E. J.; Leonard, D. Estimating 
the Range of the Maximum Hormetic Stimulatory Response. Environ. Res. 2019, 170, 337-343. https://doi.org/10.1016/J.ENVRES.2018.12.020.

(7) Calabrese, E. J.; Mattson, M. P. How Does Hormesis Impact Biology, Toxicology, and Medicine? npj Aging Mech. Dis. 2017, 3 (1), 13. https://doi.org/10.1038/s41514-0170013-z.

(8) Agathokleous, E.; Calabrese, E. J. Hormesis: The Dose Response for the 21st Century: The Future Has Arrived. Toxicology 2019, 425, 152249.

https://doi.org/10.1016/j.tox.2019.152249.

(9) Agathokleous, E.; Kitao, M.; Calabrese, E. J. Environmental Hormesis and Its Fundamental Biological Basis: Rewriting the History of Toxicology. Environ. Res. 2018, 165, 274-278. https://doi.org/10.1016/j.envres.2018.04.034.

(10) Agathokleous, E.; Kitao, M.; Calabrese, E. J. Hormesis: A Compelling Platform for Sophisticated Plant Science. Trends Plant Sci. 2019, 24 (4), 24-37. https://doi.org/10.1016/j.tplants.2019.01.004.

(11) Agathokleous, E.; Araminiene, V.; Belz, R. G.; Calatayud, V.; De Marco, A.; Domingos, M.; Feng, Z.; Hoshika, Y.; Kitao, M.; Koike, T.; et al. A Quantitative Assessment of Hormetic Responses of Plants to Ozone. Environ. Res. 2019, 176. https://doi.org/10.1016/j.envres.2019.108527.

(12) Poschenrieder, C.; Cabot, C.; Martos, S.; Gallego, B.; Barceló, J. Do Toxic Ions Induce Hormesis in Plants? Plant Sci. 2013, 212, 15-25. https://doi.org/10.1016/j.plantsci.2013.07.012.

(13) Belz, R. G.; Duke, S. O. Herbicides and Plant Hormesis. Pest Manag. Sci. 2014, 70 (5), 698-707. https://doi.org/10.1002/ps.3726.

(14) Wong, P. K.; Chang, L. The Effects of 2,4-D Herbicide and Organophosphorus Insecticides on Growth, Photosynthesis, and Chlorophyll a Synthesis of Chlamydomonas 
Reinhardtii (Mt +). Environ. Pollut. 1988, 55 (3), 179-189.

(15) Belgers, J. D. M.; Van Lieverloo, R. J.; Van der Pas, L. J. T.; Van den Brink, P. J. Effects of the Herbicide 2,4-D on the Growth of Nine Aquatic Macrophytes. Aquat. Bot. 2007, 86 (3), 260-268. https://doi.org/10.1016/J.AQUABOT.2006.11.002.

(16) Peres, L. R. S.; Della Vechia, J. F.; Cruz, C.; Peres, L. R. S.; Della Vechia, J. F.; Cruz, C. Hormesis Effect of Herbicides Subdoses on Submerged Macrophytes in Microassay Conditions. Planta Daninha 2017, 35 (0). https://doi.org/10.1590/s010083582017350100076.

(17) Allender, W. J.; Cresswell, G. C.; Kaldor, J.; Kennedy, I. R. Effect of Lithium and Lanthanum on Herbicide Induced Hormesis in Hydroponically-grown Cotton and Corn. $J$. Plant Nutr. 1997, 20 (1), 81-95. https://doi.org/10.1080/01904169709365235.

(18) Americo, G. H. P.; Americo-Pinheiro, J. H. P.; Furlani JR, E. Hormesis Effect of Dichlorophenoxy Acetic Acid Sub-Doses and Mepiquat Chloride on Cotton Plant. Planta Daninha 2017, 35 (0). https://doi.org/10.1590/s0100-83582017350100078.

(19) Scherer, G. F. E.; Morre, J. In Vitro Stimulation by 2,4-Dichlorophenoxyacetic Acid of an ATPase and Inhibition of Phosphatidate Phosphatase of Plant Membranes. Biochem. Biophys. Res. Commun. 1978, 84 (1), 238-247.

(20) Shivani; Tiwari, S. Enhanced Agrobacterium-Mediated Transformation Efficiency of Banana Cultivar Grand Naine by Reducing Oxidative Stress. Sci. Hortic. (Amsterdam). 2019, 246, 675-685. https://doi.org/10.1016/J.SCIENTA.2018.11.024.

(21) Veraplakorn, V. Allelopathic Hormesis and Slow Release of Lantana (Lantana camara L.) Callus Extract. Agric. Nat. Resour. 2018, 52 (4), 335-340. https://doi.org/10.1016/J.ANRES.2018.10.004.

(22) Wort, D. J. Increased Tuber Yield of Pontiac Potatoes Resulting from the Foliar Application 2,4-D-Mineral Dusts. Am. Potato J. 1965, 42, 90-96. 
(23) Furlani Junior, E.; C., E. R.; Vitor Ferrari, S.; Aires dos Santos, D. M.; Gouvea Luques, A. P. P.; da Silva Vieira, H. S. Efeito de Subdoses de 2,4-D Sobre Componentes Da Produção Do Algodoeiro. In Anais do $8^{a}$ Congresso Brasileiro de Algodão; Campina Grande: Embrapa Algodão, 2011; pp 599-604.

(24) Beevers, L.; Peterson, D. M.; Shannon, J. C.; Hageman, R. H. Comparative Effects of 2,4Dichlorophenoxyacetic Acid on Nitrate Metabolism in Corn and Cucumber. Plant Physiol. 1963, 38 (6), 675-679. https://doi.org/10.1104/pp.38.6.675.

(25) Dragicevic, V.; Sredojevic, S.; Djukanovic, L.; Srebric, M.; Pavlov, M.; Vrvic, M. The Stimulatory Effects of 2,4-D as Hormetic on Maize Seedling’s Growth. Maydica 2007, 52, 307-310.

(26) Feung, C.; Mumma, R. O.; Hamilton, R. H. Metabolism of 2,4-Dichlorophenoxyacetic Acid. VI. Biological Properties of Amino Acid Conjugates. J. Agr. Food Chem. 1974, 22 (2), 307-309.

(27) Hicks, C.; Morré, D. J. Oxidation of NADH by Intact Segments of Soybean Hypocotyls and Stimulation by 2,4-D. Biochim. Biophys. Acta - Biomembr. 1998, 1375 (1-2), 1-5. https://doi.org/10.1016/S0005-2736(98)00114-X.

(28) Miller, M. D.; Mikkelsen, D. S.; Huffaker, R. C. Effects of Stimulatory and Inhibitory Levels of 2,4-D, Iron, and Chelate Supplements on Juvenile Growth of Field Beans. Crop Sci. 1962, 2 (2), 111-114.

(29) Miller, M. D.; Mikkelsen, D. S.; Huffaker, R. C. Effects of Stimulatory and Inhibitory Levels of 2,4-D and Iron on Growth and Yield of Field Beans. Crop Sci. 1962, 2, 114 116.

(30) Patil, V. A.; Kale, V. R. Yield and Protein Content of Wheat Varieties (Kalyansona and Ni-5642) as Influenced by Sublethal Doses of Herbicides. Qual. Plant. Plant Foods Hum. Nutr. 1975, 25 (2), 187-192. https://doi.org/10.1007/BF02591039. 
(31) Mahmoudinia, S.; Niapour, A.; Ghasemi Hamidabadi, H.; Mazani, M. 2,4-D Causes Oxidative Stress Induction and Apoptosis in Human Dental Pulp Stem Cells (HDPSCs). Environ. Sci. Pollut. Res. 2019, 1-14. https://doi.org/10.1007/s11356-019-05837-0.

(32) Marques, R. F.; Marchi, S. R.; Pinheiro, G. H. R.; Souza, R. M.; Assunção, H. F.; Lúcio, F. R. Hormesis of 2,4-D Choline Salt in Biometric Aspects of Cotton. J. Agric. Sci. 2019, 11 (13), 283-294. https://doi.org/10.5539/jas.v11n13p283.

(33) Dragicevic, V.; Spasic, M.; Simic, M.; Dumanovic, Z.; Nikolic, B. Stimulative Influence of Germination and Growth of Maize Seedlings Originating from Aged Seeds by 2,4-D Potencies. Homeopathy 2013, 102 (3), 179-186. https://doi.org/10.1016/J.HOMP.2013.05.005.

(34) Agathokleous, E.; Calabrese, E. J. Hormesis Can Enhance Agricultural Sustainability in a Changing World. Glob. Food Sec. 2019, 20 (C), 150-155. https://doi.org/10.1016/j.gfs.2019.02.005.

(35) Agathokleous, E.; Kitao, M.; Calabrese, E. J. Hormetic Dose Responses Induced by Lanthanum in Plants. Environ. Pollut. 2019, 244, 332-341. https://doi.org/10.1016/j.envpol.2018.10.007.

(36) Agathokleous, E.; Araminiene, V.; Belz, R. G.; Calatayud, V.; De Marco, A.; Domingos, M.; Feng, Z.; Hoshika, Y.; Kitao, M.; Koike, T.; et al. A Quantitative Assessment of Hormetic Responses of Plants to Ozone. Environ. Res. 2019, 176, 108527. https://doi.org/10.1016/j.envres.2019.108527.

(37) Li, R.; He, J.; Xie, H.; Wang, W.; Bose, S. K.; Sun, Y.; Hu, J.; Yin, H. Effects of Chitosan Nanoparticles on Seed Germination and Seedling Growth of Wheat (Triticum Aestivum L.). Int. J. Biol. Macromol. 2019, 126, 91-100. https://doi.org/10.1016/J.IJBIOMAC.2018.12.118. 